1932

\title{
Conquest of pernicious anemia
}

\author{
Ferrall H. Moore \\ University of Nebraska Medical Center
}

This manuscript is historical in nature and may not reflect current medical research and practice. Search PubMed for current research.

Follow this and additional works at: https://digitalcommons.unmc.edu/mdtheses

Part of the Medical Education Commons

\section{Recommended Citation}

Moore, Ferrall H., "Conquest of pernicious anemia" (1932). MD Theses. 223.

https://digitalcommons.unmc.edu/mdtheses/223

This Thesis is brought to you for free and open access by the Special Collections at DigitalCommons@UNMC. It has been accepted for inclusion in MD Theses by an authorized administrator of DigitalCommons@UNMC. For more information, please contact digitalcommons@unmc.edu. 


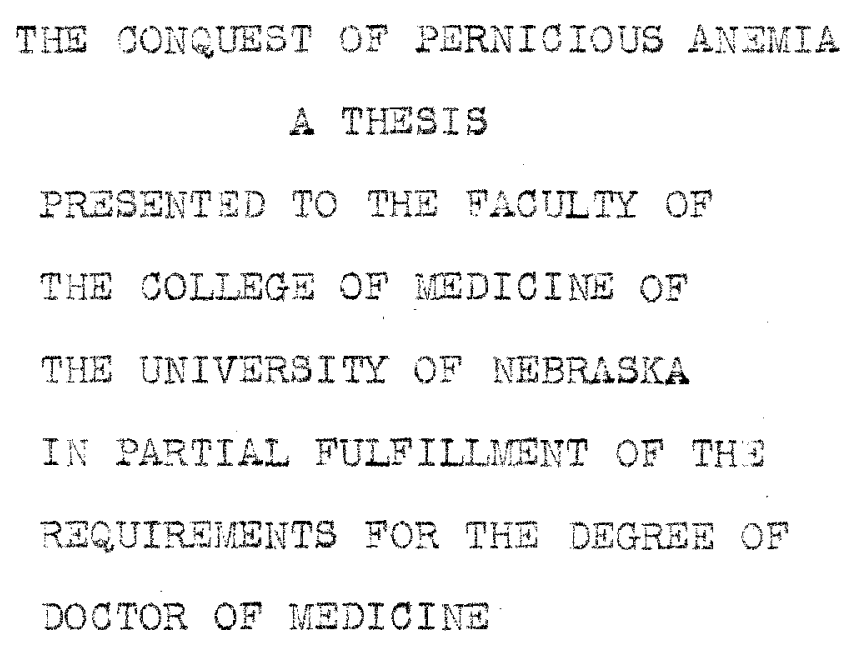

FERRALI HARMON FOORE

APRIL I5,I932 


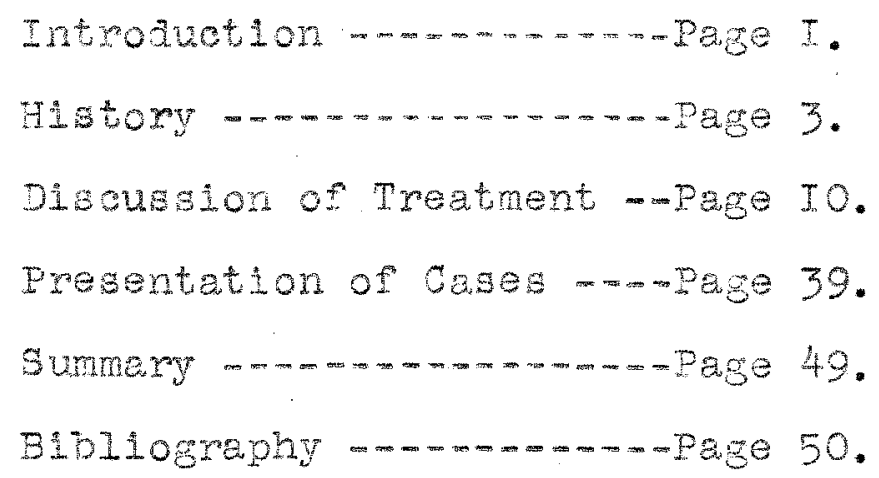




\section{INTRODUCTION}

The year following the close of the decade between I920 and I930 would seem a particularly opportune time for a glance in retroapect over the epochal contributions which have so enriched mical science, and which have made this period one of outstanding importance.

In no fiela of achievement can be found two feats more brilliant or of greater benefit to humanity than the conquest of those dread scourges--- Diabeteg Mellitus, and Pernicious Anemia. Long treated only by empirical and merely palliative methods, these two diseases had come to be held by both laity and the profession as synonymous with despair and helplessnes; as each took its annual toll of thousands while loved ones and medical men were forced to watch, powerless. The announcements of Banting and Best, and of Whipple, Murphy, and Minot thus came as pure light in the midgt of what had been comparative darkness, and granted both reprieve to many thousands of sufferers and hope to generations to come. What chapter in any history can rival the discoveries of these few men:--- elther for colorful triumph or for bearing on the Iives of those unborn?

The writer has chosen a phase of the conquest of

Pernicious Anemia as the subject of this paper, and he feels that this particular phase relates more vividly and succinct 
$-1 y$ than any other the change in the various aspects of this disease, as viewed during the past decade. The treatment, with which this paper deals, by its revolutionary change in I926 and the years following, epltomises well the resulting change in our ideas as to prognosis and possible etiological factors to be considered in any discussion of the subject.

Hence, as the writer seeks, both by citing history, exp-eriment, and actual hospital cases, to delineate such changes as have been brought about, it is with a feeling of futility, since words, diagrams, and records are but feeble instruments with which to paint the picture of such long-sought and painstaking achievement. It is only bare justice to say that Medicine owes a great debt of gratitude both to those who brought research on this subject to its recent cuimination, and to those unknown ones who, through bygone forgotten years, sought vainly to solve the ridale and in so doing left stohes on which their followers might step to reach the higher. 


\section{HISTORY}

Since this paper is essentially a history of the prog-ress of the treatment of Pernicious Anemia,with a studied endeavor to exclude any other phases of the subject than the one here treated, such as etiology, pathology, symptomatology, or prognosis, any historical mention of treatment would be included under the main discussion of this subject. Hence the writer believes it best to consider the historical data of this paper as bearing on the history of the disease, Pernicious Anemia, as an entity, from the first time at which it came within the ken of the medical world; in so doing it is his purpose to furnish a contemporary historical back-ground for the later consideration of the changes in trend of its treatment. To attempt a resume of the several thousand papers of historlcal interest on the subject would be out of the scope of this one paper, but, by clting those contributions of outstanding import -ance, the milestones in the advance of our knowledge may be pointed out.

In I88I Ehrlich made his discovery of the value of aniline dyes in the staining of blood films, and hematology as a distinct subject may be said to date from this time. Without the benefit of the blood pleture it is no wonder that the early accounts of the anemias were confusing and at variance. In the

literature which has accumulated on the subject, however, certain contributions stand aut above the rest, and the development of 
our conception of Perniclous Anemia will be found to run in close sequence with them.

The first paper to hint at the existence of such an entity 8.5 an "ldiopathie",primary type of anemia, came in I824 from a Scotch physician, Dr.J.S.Combe. This contained an excellent description of a case of anemia which had come under his care, and would still fit nicely into a modern text-book descript-ion. He stated "that if any train of symptoms may be allowed to constitute anaemia a generic disease, the following may be considered an example of it in its most idiopathic form", and suggested that "it is probably owing to some disorder of the digestive and assimilative organs that its characteristic symptoms have their origin".

From this time until I855, several accounts appeared in the literature of very severe anemias, which, statea Gulland and Davidson, were in all probability cases of pernicious type. Barclay, in I85I, was the first to note the presence of glossitis in a patient dying from a severe anemia.

Dr.Thomas Adaison, of Guy's Hospital, in I855, gave an excellent description of a case of pernicious anemia as a preface to his paper on "constitutional and local effects of dis- ease of the supra-renal capsules", the type of severe anemia yet bearing his name. Finding no cause for such anemia, he termed it "liopathic", but unfortunately his work made little impress -ion on the medical profession in his own country or on the continent. Later however, in I878, his claim to priority to later 
workers was acknowledged by Elchhorst, when he wrote "that this digease was first described in England both in the form of single casea and as a definite clinical disease."

In I867, and again in I872, Profes sor Blermer, of Zurich published papers describing a very severe anemia, which he gave the name of Progressive Perniclous Anemia.His descriptions of the clinical and post-mortem findings were practically the same as those of Addison, but attracted much more widespread recogn-ition than those of the latter. However, while Addison held that the distinguishing feature of the disease was its idiopathic nature,Blemer stated that the absence of clear etiolo-gical factors was the exception, and, in short, included under the title of Progressive Pernicious Anemia a group of condit-ions of which one was the idiopathic varlety described by the earlier author. "Hence", to quote Davidson, tho quotes Cornell, "It became an international medical pastime to exclude cases from publighed reports on the basis of purity of type,each of the critics employing his own standard of judgement." From this time on, Pernicious Anemia was known both as Addison's An- emia and as Morbus Biermer.

During the next fifteen years other workers tended to uphold Blermer's view of the disease, among whom were Quincke, Immerman, and Eichhorst.An Englishman, Pye-Smith, was the only one of note to uphold the concept of Addison.

During the two years I875-6 two independent workers, William Pepper, and J.Cohnheim, both added to the general fund of knowledge of the disease by first calling attention to the 
megaloblastic appearance of the marrow of patients dying of this stange anemia. Particular atress was laid by Cohnheim on the disparity between the anemic condition and the increase

- in the red marrow of such patients.

In I887, another fragment was added to the clinical picture of the disease by Lichtheim, whose article firat called attention to the degenerative changes taking place on the col- umns of goll and Burdach during the course of the anemia.At a.most the same time, in I886, Henry and Osler published their paper which dealt with the atrophy of the stomack with the cli -nical features of Progressive Pernicious Anemia.

From I890 to I909 one worker who added much to our conception of this type of anemia as a distinct clinical entity, involving both gastro-intestinal and nervous systems as well as the hemopoletic system, was william Hunter. We are told that he strongly chiticized Blermer's attempt to group several ane-mias, etiologically very different, under one heading, and that he malntained Addison's anemia a single entity. Among his many contributions were his observations on glossitis and gastrointestinal sepsis as related to oral sepsis and a possible but mysterious factor lying within the gut tube as a cause of the disease. However, he falled to include as a factor the very sig -nificant changes in the blood and blood-forming organs, on both of which his contemporary, Ehrlich, lald great stress.

While, a.s stated previously, Pepper and Cohnheim were the first workers to call attention to the megaloblastic type 
of bone-marrow in victims of this condition, it remained for Ehrlich and Lazarus, in I898, to go a step farther and postulate that the essential pathological and pathognomonic features of the disease were "degenerative" megaloblastic bone-marrow types of change. It is curious that of two men, working at the same period, one, Hunter, should stress the factors of infection and hemolysis, the other, Ehrlich, the factor of degenerative change of the hemopoletic apparatus.

Muir, inI 894, after investigation of bone-marrow from patients dying of the disease, concluded that the changes he found there could be interpreted as compensatory to destr- uction of blood cells in the portal circulation.Quincke, in I877, had called attention to pigmentary changes in the Iiver, but had attached little importance to his finding.

Further work by many investigators brought the extreme vlews of Hunter and Ehrlich closer together, and it was admitted that the condition of the gastro-intestinal tract and the evidences of hemolysis were as much a part of the clin - ical syndrome as the bone-marrow changes. The question of the primary hemolytic site still remained unsettled, however, Hunter clting Muir's views as evidence of the secondary importance of the blood formation in relation to portal hemolysis, and statins that these changes were most marked when siderosis was present in the highest degree. Ehrlich and his proponents, however, would see only the converse, namely that siderosis was most prominent when the megaloblastic degeneration was at its greatest. 
The past ten years has brought further light to bear on the nature of this disease. Achlorhydria has come to be held as one of the cardinal signs of the condition. Pigment metabolism is better understood, recent investigators such as Roux having added to the earlier knowledge given us by Minkowski and Naunyn, and the importance played by extra-hepatic struct-ures, in short, the vast "reticulo-endothelial"system as first proposed by Aschoff-Landau, in the metabolism and disposition of the pigments of the blood has come to the fore. Of especial interest is the view recently propounded by $P$ iney, in regard to hereditary and congenital factors having to do with the disease we are considering. His studies of the bone-marrow in Pernicious Anemia have led him to believe that there is in the victims of this disease a developmental defect by which there is inadequate development of adult (normoblastic) bone marrow, and a compensatory hypertrophy of fetal (megaloblastic) bonematrow. Through the action of some exciting cause, which may be the broad tape-worm, syphilis, pregnancy, or that which causes the"ldiopathic" anemia, with this developmental defect as a weak link in the chain, Piney believes that the signs and the symptoms of Pernicious Anemia are produced.

Finelly, the recent revolutionary change in treatment, that of successul therapy by liver, dessicated stomach, and predigested muscie-meats, has hinted to us that our concept- ion of this aisease entity should include as etiological factors those of both constitutional element and deficiency, 
and we are impressed by the course of the development of our presenti-day conception of Pernicious Anemia as a clinical entity as we have revieved the various contributions and the many controversies by which this present-aay concept has been attained. Undoubtedly, as severe a menace as it has been since we have recognised the disease as a distinct entity, it had for years beyond number been an obscure cause of death to menkind, and the separation of Pernicious Anemia as a dsease for which there is now a rational treatment fumishes bright contrast to what hopeless a picture must have been seen before the conditi - Ion was even recognised as at present. 


\section{DISCUSSION OF TREATMENT}

The discussion of the various agents used in the treatment of Pernicious Anemia properly beging with the consid- eration of the period included between the recognition of such a disease entity and the present time. Many of the older agents of therapy had long been known and used prior to the segregation of this particular type of anemia from the other blood dyscrasias, and are to be mentioned here only in the the light of their appl-ication to this condition.

Perhaps the two oldest therapeutic agents known in the treatment of those conditions characterized by the clinical manifestations of anemia are blood and iron. The former has been used in therapeutics by uncivilized peoples since time unknown, in the form of fresh blood, dried blood, or drled blood mixed with various dubious ingredients and aided by divers incantations. The latter has been used in therapeutics since the earliest known his-tory of pharmacy, becoming more prominent during the astrological period of that soience, when it was inseperably connected with the planet Mars as it appeared in the patient's horoscope. This period reached its height in the fifteenth and sixteenth centuries. The Ines of Garth (I706) reveal the esteem in which it was held at that date in the treatment of "the green sickness" (Chlorosis).

-...-. Till the Green Sickness and Love's force betrayed To Death's remorseless arms the unhappy maid. ***** Oh, that instead of trash, she'd taken steel! " 
Mandel, a French physician of I804, gave loud acclaim to the virtues of "les boules d'acier de Nancy"-.... pellets of Iron and Potassium tartrate, recommending them as a sovelgn remedy for post-hemworhagic anemia, chlorosis, and anemia from other causes.

A search of medical literature immediately following Combe's first description of a case of Pernicious Anemia in the year I824 fails to reveal any suggestions as to it s treatment. In Guy's Hospital Reports of I836, however, Ashwell made certain ob-servations on the treatmant of Chlorosis, many cases so diagnosed quite possibly being a pernicious type. His account will bear repetition ....-" I first commence treatmant by special attent-ion to the digestive organs and alimentary canal, for I regard the disorders of these as a cause, second only to the peculiarity

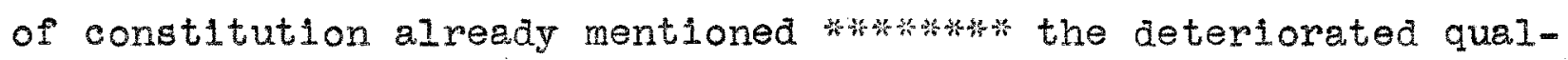
-ity of the blood and its defective quantity may both owe their origin to impaired digestion and nutrition. At rinst, then, a due evacuation of the bowels must be daily secured; and much will depend on the kind of medicine by wich this is effected. If Mercury and drastic purgatives be frequently and largely employed,irritam

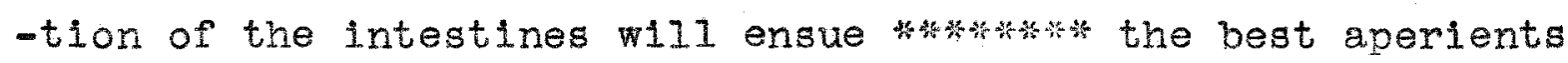
are aloes, rhubarb, sulphate of soda and manna, and, if an alterative be necessary, Hydrargyri cun creta. An injection of warm water into the rectum two or three times a week will work wonderfully as a stimulant to inteatinal movement." Among the purgatives which he

- recomends are the following -.-

F Pulv. Rhes 3fs. Mag. Subcarb.3fs. Conf.arom. J1.Aq. Cinnamoni 3ix Tinct.Card.Co.31. in. ft. Haust. bis terve in sept. sumendus. 
"Second", says Ashwell, "I recommend warm clothing, regular exercise; nutritious animal diet and a mid malt liquor will be productive of benefit. The improvement of the digestive organs indicated by the return of appetite and the healthier condition of the bowels is evinced by their natural dally evacuation. At this orisis, some of the preparations of Iron may be exhibited, and the sulphate is probably the most efficacious, and possesses more specific qualities than any of the reat. If the order of procedure, now pointed out, be reversed --. If the iron be used before the bowels have been freely evacuated and their functional action improved, or while the tongue is loaded and foul, aggravation of the symptoms will be produced; while if there be only the peculiar debility and pallor then the iron may be most beneficially used. Occasionally the effect of the iron is almost magical, especially where it does not confine the bowels or induce febrile heat. The following forms may be preacibed.....-

R. Ferri Amm.3ifs, Extr.Humuli et Extr.Papav.alb. aE gr.xv., Oleum Cassiae m.xv. M. ft.pil.xxiv. Sumat 1 vel il bis terve quotiaie. B Ferri Subcarb.gr.vili., Pulv.Ipecac gr.i.,Hyar.e Cretae gr.i1. B. Ferri Iodidi gr.xvi., Tinct.Calumba vel Gent.Co. J1,Aq.Dist. Juil. M. ft. Mist. Sumat coch.ii magna, bis terve quotidie. Quinine,Sarsaparilla,Gentian, and Zine are all remedies also of acknowledged power". Thus, from the type of treatmant set forth in this paper,almost a century ago, we may see what were then - the prevaling ideas as to the treatment of anemia, a conglomerate term, with little distinction as yat made between its various types. 
From this time until I877, despite the early controv-ersies in regard to the entity of Pernicious Anemia, ittle or no advance in its treatmant appears. At this time Dr.Byrom Bramwell, an English physiclan, annonnced the cure of a case of Pernicious Anemia by the use of Arsenic. It is debatable as to whether or not this was a true case of this aisease,as the study of the dyestained bloodfilm did not begin until the discoveries of Ehrilch, several years later. However, due to the discussions of Addison and Biermer and their respective adherents, such an entity as a distinct Pernicious Anemia was recognized, advance in treatment to the contrary.

The year I 880 brought one advance in therapy in the form of the first blood transfusion performed on a case of Pernicious Anemia,by Starr, an American physician -...- a method of treatmant which was to remain as one of the sheet-anchors until the advent of modern therapy. However, in the same year, the prevailing methods of treatmant were again reflected in a paper by Taylor, an Englishman. A short list of medication used by him is of interest, and indicates the trend to alteratives and symptomatic measures -..R Tr. Ferri Perchlor. m xv., Inf.Quassiae 4 tid. By Ale, 01 da1ly. B 01. Phosphorati mi., Aq. menth.pip. ऊ, Nucilage zi tid. Quinine, digitalis, and Aromatic Spirits of Ammonia were also used in various cases by this writer.

Two years later, Pye-Smith, a pupil of Addison, publish-ed a repott of a case treated by him, in which the medication leaned on the effects of Arsenic and other alteratives for its effect. A list of agents used in this case is of interest,as it 
seems to be a good example of the medical armamentarium against Pernicious Anemia at this time,excluding the newly introduced agent of blood transfusion.

Ry Phosphate perles tid.

Ry Liq.Arsenicalis m v,Tr.Chlorof.m xv., Aq.ad $3^{1}$. tas. Ry Pot.Iod.gr.vi1., Ferri et Amm.Citr.gr.x., Inf.Calumba, Aq.menth. pip. $\widehat{a}$ 3iv. Ter die sum. R. O1. Morrhuae, 311 tds.

This list of medicaments, making use of Arsenic, Iron, Phosphorus, and 01.Morrhuae in truth represent the half of therapeusis of Pernicious anemia almost to the present time, but by their alt-erative nature betrey the dearth of any type of treatment for a recognisedy specific disease.

While by the year I890 a great deal had been written pro and con as to the nature, etiology, and prognosis of this disease, I have found no instance in which the miters have attempted to depart from time-honored means of treatment and work out a rational method, coupling etiology and treatmant in their reasondng, until William Hunter, who first published a paper on Perniclous Anemia at this time. Up until the present time no worker has given more imp- etus to the study of this subject than he, and his papers in the British Hedical Journal are worthy examples of careful thought and painstaking effort. The theory of a gastro-intestinal toxin as a factor in the production of Pernicious Anemia,propounded by him, has greatly influenced thought on the subject to the present day, and has, so far as I know, never been disproven. Also praiseworthy was his stand with Addison, against the German achool, namely that 
Perniclous Anemia should stand as a pathological and clinical entity in itself, and not be classified among other types of socalled Progressive Pernicious Anemia. His summary of treatmant, while rather long to be quoted verbatim, shows such sound reason and so reflects the change from empiric to rational thought that I venture to quote it in full in this paper. -......." The object of my investigations into this disease has been by elucidating its true nature to establish a basis for its rational treafment. There are, I believe, two Indications-first, To remove the cause, with the attendant gastro-intestinal conditions favoring its op-eration. This indication of treatmant can only be suacessfully fulfilled when the local conditions favoring its operation can

- also be removed. Cases belonging to this group are those***where recovery has raplaly followed the removal of worms---Bothrioceph-alus latus and Anchylostoma duodenale---- from the gastrointest-inal tract. The moat important point, therefore, to be attended to in diagnosis, after the true (hemolytic) nature of the anema has been recognised, is to determine what the favoring condition 1 . In the hope that it may be an unhealthy condition of the stomach or intestintal mucous nembrane, induced by the presence of intest-inal worms, free movement of the bowels should always be encoura-ged in the earlieb stages of the disease. Where it is recognised to be of a more permanent character---for example, Gastritis, Atrophy of mucous membrane of stomachman the problem of treatmant becomes more difficult. It is in such cases that the advisability of washing

- out the stomach wiIl have to be considered. Such a treatment was first suggestad by Sandoz on the view that certain of the aymptoms 
were those of indigestion, and that the products formed as the result of indigestion might in this way be removed. I have shown that these products are of an entirely different character from from those had in view by Sandoz, and further, that they are formed not so much, if indeed at all, in the contents as in the wall of the stomach itself. How far such a plan of treatment will prove successful under such clreumstances may be open to doubt. It is one, however, which I concelve might be adopted with advantage in

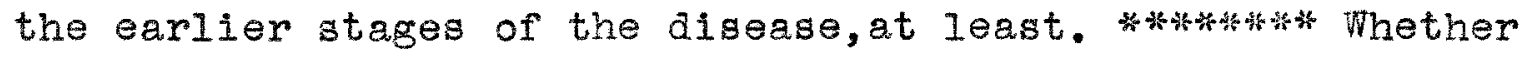
nelther the cause nor the favoring condition can be attacked directly by methods such as the foregoing, it is still possible to effect the object indirectly. The beneficial action of Arsenic in cases of Pernicious Anemia, firat pointed out by Dr.Byrom Bramwell, has now come to be generally recognised. In some cases (and the foregoing is one of these) it altogether falls. Its mode of action has hitherto been usually concelved to be in accordance with the views prevalent as to the nature of the anemia, by stimulating blood formation. I concelve that pts action in such ca ses may be more simply explained as an entirely local one on the mucous membrane

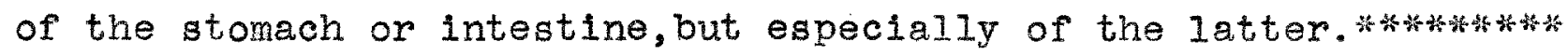
Any beneficial action Phosphorus may have in certain cases is prob -ably to be similarly ascribed to its local action.

The presence of special micro-organisms as an essential factor in such cas naturally suggests the use of drugs having antiseptic properties. The one I have tried, and the one I believe the best suited for internal use, is beta-naphthol. It possesses in a special degree the two properties essehtial for an intestinal 
antiseptic, namely, great disinfecting power, with, at the same time, great insolubility in water;its antiseptic power is three times that of iodoform. I used $1 t$ in the foregoing case during the lat-ter few weeks of the patient's illness, too late, however, to derive any benefit from its action. It can be given in doses of Gr.v,tid, suspended in mucilage.

The second indication is to combat the symptoms. The most important of these is the excessive destruction of blood induced by the absorption of the poisons. It is the continual drain on the blood thus brought about that causes the intenge anemia and the excessive weakness. The best way of combatting this--apart from the removal of the cause-..-- I concieve to be, by regulation of the det, with a view to diminish blood destruction as far as possible. The most important factor regulating the amount of blood destruct-Ion in health I find to be in the nature of the diet, a nitrogenous diet causing a much greater destruction than a farinaceous or fatty one. The blood destruction which occurs in this disease so greatiy exceeds, however, that of health, and depends upon the operation of such different factors---the formation and absorption of specific poisons of the nature of Ptomines---that the difference between a nitrogenous and a non-nitrigenous diet may be of comparatively Iittle moment. Nevertheless, the results obtained in the present case suggest that such is not the case. The patient was placed on a more farinaceous diet on March Ioth, his previous diet having been made up of beef-tea, extracts of meat, etc. The effect of this treatment was at once noticeable, and was evidenced at once by an entire disappearance of blood pigment granules from the urine, and 
by the subsequent improvement in the patient's geberal condition. After his attack on April 20th, I placed him on a purely milk diet. The disease was, however, too far advanced to permit of successful treatmant. I deemed it desirable, in the results obtained after a change of the diet in the present case, to obtain some further data as to the effect of a more exclusively farinaceous diet on the change occurring within the intestine.******\%The method adopted was to determine the relative excretion of free and aromatic sulphates in the urine on (1) a mixed diet, and (2) on a more exclusively farinaceous one. * * to aromatic sulphates (conjugated with phenol, indol, skatol, and cresol) was on the average as 9 to I.the effect of a more farina-ceous diet was to reduce the excretion of aromatic sulphates (representing the amount of putrefactive loss occurring in the food within the intestinal canal) by more than one-half, with an average ratio of I5 to I. The result may be expressed in this way---that with an almost equal quantity of food of both kinds, the amount of $10 s$ a de to putrefactive changes within the intestinal tract dim-inished by more than one-half by the use of a more farinaceous di -et; at the same time there was an increase in body weight. It is on these grounds that I believe good results may be expected from a more exclusively farinaceous diet in eases of Pernicious Anemá" Thus, in this carefully thought-out summary of treatment, in which Hunter endeavoed to swing the tide from the empiric to the rational, two new angles of attack are added to the therapy of this disease-..-. Intestinal antisepsis, and Dietary regime. While the 
idea of diginfecting the intestinal tract has since been proven fallacious, and the farinaceous dietery proposed by Hunter has been placed at veriance with the modern detetic regime, this one contribution represents a well-pianned Ine of treatment in the light of Hunter's conolusions, and stimulated thought along the Ine of the importance of foods in the treatment and possible cure of this a1sease. It is, however, regrettable that Hunter, in his zeal to prove that the disease was primarily due to a hemolytic factor, neglected to consider seriously the significance of the stained blood-film and the characteristic bone-marrow changes so emphasized by his contemporary and critic, Paul Ehrlich.

Regardless of the amount of data published by workers of the German school, during the period of the Hunter Ehrlich debate, it is significant that we do not find in the literature any new advances of any importance which come from the Teuton. However, the careful study and speculations advanced by this group, having to do with the marked changes in the hemopoietic organs in this disease, emphasized another very important part of the whole picture, and further atimulated thought down to the immediate present. Hale White, connected with Guy's Hospital, was the next to publish a summary of results of treatment of a number of cases,all diagnosed as Pernicious Anemia.Quoting him in brief--- "We thus learn that although geveral patients have been known to recover from their first, ot even their second attack, nevertheless even then almost invariably they soon relapse and die, and that general -ly within a year. Most of the cases that have been benefitted have taken Arsenic." 
The next advance in treatment was suggested by Fraser, a physiciar in Edinburgh, who instituted the feeding of marrow to patients. His first case was cited briefly as pollows-.- " In I893 this measure was first tried. Ox and calf bone-marrow, not cooked, were given by mouth to a patient who had falled to respond to Ferrous Chloride and Liquor Argenicalis dally. At the beginning of the marrow feeding the red cell count was 843,000 , and the hemoglobin percentage I8. After three weeks with Arsenic, Iron, and the Marrow, the red cell count had misen to I, 800,000 , and the hemoglo-bin percentage to 35. Arsenic, Salol, and Marrow were then given over a period of 26 days, at the end of wich time the red cell count came to $2,470,000$, and the percentage of hemoglobin to 55 . For a further period of 32 days the patient received ox and calf bone-marrow with Salol,gr.xxx daily. At the end of this time the red cell count was 4, 100,000, and the hemoglobin percentage $75 . "$

While later critios have questioned these results on the ground that the marrow was not given alone to determine its effect, and that this was possibly not a pure case of Pernicious Anemia, it is significant that in this regime of treatment we see combined the results of both Hunter's and Ehrlich's views, in the use of an intestinal antiseptic and of specific detary measures, and in the recognition of a possible marrow defictency or abnorm$-a .11 t y$.

Five years later, in I898, Coupland, in Allbutt's System of Medicine, summarizes the then accredited agents of therapy in dealing with Pernicious Anemia. These were --- Rest; Diet of a predominantIy farinaceous type,to which might be added peptonized 
foods, pounded raw meat, and bone marrow; Iron, best given in the form of the perchloride; Arsenic, the sheet-anchor of treatment, given as Fowler's solution or as Iiquor arsenicl hydrochloricus; Intestinal antisepties, such as Salol,Beta-naphthol,or Bismuth Selicylate;Transfusion; and Gastric Lavage. In conclusion, he states --- "Pernicious Anemia, then, tends ordinarily to run a downward course, often uninfluenced by any treatmant used; freq-uentiy, when marked improvement has followed use of certain rem-edies, a relapse has occurred in which the same means are no long -er successful." This one provigion, coming at the end of a long list of therapeutic agents, serves well to reflect the efficiency of all treatment known to the best medical men of the time, and to show the well-high hopeless attitude adopted in regard to the disease both by the laity and the profession.

Until I9I3 no new Ideas of treatment of any importance were advanced, and at this time both Bramwell and Boggs began the use of Salvarsan on cases coming under their attention. Bramwell treated II cases in this manner, 4 of which seemed cured, 2 showed marked improvement, I slight, 2 giving no indication of improvement, and 2 succumbing. Boggs likewise treated II cases, 9 of whom were reported as improved, 2 succumbing.

Hobart Hare, summing up the measures of therapy in I9I8, comments on the addition of dilute Hydrochloric acid to the list, and concludes as follows -.. " In Pernicious Anemia, splenectomy and repeated transfusions are to be considered, and very pronoun-ced, but unfortunately only temporary good results follow the free use of Arsenic by mouth or its hypodermic employment in the 
form of Sodiun cacodylate. Diet is an important part of the treatment of anemia. The food should be good, well-flavored, and varied,as well as easy of digestion. It should contain as far as possible the remedies needed by the system, such as bone salts and iron, and its ingestion may be accompanied by some red wine, such as port." surely no significant advance of thought here! Wilison and Evans, analysing the dinical histories of II cases of Perniclous Anemia treated in London Hospital from I909 to I9I9, found that, dating from the time of admission, within 3 months 3I.2\% of these patients were dead, within 6 months, 43,9\%, and within 9 months, 52.6\%. At the time this paper was published, in I928, only I of the originaI II4 was living. Surely a pitiful result for all of the years of research and controversy as to the etiology, nature, and treatmant of this diseage:

Sir Rendle Short, in his"Index of Prognosis and End Results of Treatment", published in I922, takes inventory of all the measures previously clted, and make the following significant statements -..- "As regards medicine, no drug can yet be sald to compete seriously with Arsenic, and an important element in pros-nosis is the way the patient responds to it. **** I do not belleve Salvarsan or Neo-Salvarsan to be of value save for such febrile reaction produced by 1. .**** Iron does harm rather than good in most cases of Pernicious Anemia, but is sometimes good in the course of recovery, when the color index is low. benfit derived from the administration of Anti-streptococcus serum from the serum reaction, not from an anti-streptococcus element. ******* Blood transfusion is a measure usually reserved 
for desperate cases. Practically all patients are improved for a longer or shorter time; in several ases a remission followed, though the subsequent history of the disease was not influenced. ****** Splenectomy has often been performed as a treatment for Pernicious Anemia; but. while the initial risk is great, the subsequent history of the cases which have been followed up is not such as to encourage us to adopt the procedure. ****** One of the remarkable features of the diease is the occurrence of remiss-ions. They sometimes begin quite abruptly, even though severe symptoms are present, and their occurrence is often attributed to the exhibition of medicines which had no part in bringing about the improvement. Not only is the chance of a remission greater after a first than after a subsequent attack, but after a first one there is a much greater likelihood that, if a remission occurs, it will be more complete and more prolonged than after a second or subsequent relapse." These almost nihilistic state -ments serve well to indicate the skepticism of this writer as he surveys the woefully inadequate means of treatment at his command with thich to combat this baffing malady, and illustra-tes the general feeling in the medical world at this time.

Medicine now stbod on the threshold of the period of discovery which was to change the whole aspect of treatment of Pernicious Anemia. During the same year in which Sir Rendle Short wrote so despairingly of any valuable treatment, an American, Fitch, had the secret within his grasp, but, failing to comprehend the significance of his idea, did not get it across to the prof- 
ession at large. In his work on Dieto-therapy, he recommends that bone-marrow, liver, and spleen be included in the dietary of the sufferer from Pernicious Anemia, but justifies his statement on the ground that these foodstuffs are rich in nucleoalbumins contalning iron. He further proves that he does not appreciate the significance of his statement by remarking---" the life of the patient may be prolonged and a reasonable degree of confort secured through careful supervision of digest-ion and elimination, though there is no specific evidence that diet per se modifies the course of the disease."

However, for the previous several years another Ameri-can worker, Whipple by name, and his associate, Robscheit-Robbins, of Rochester, had interested themselves in the effects played by various diets in influencing blood regeneration in animals rendered anemic by hemorrhage, and it was through this beginning that the great discovery was to be made which was to conquer the disease which for so many years had baffled science.

"These observers, working with dogs, in I920, had determined for each animal the 'available red cell pigment; by observations of the hemoglobin percentage and the blood volume. They then produced a uniform degree of anemia by the removal, on each of two successive days, of one-quarter of the already determined blood volume. The time taken for the available red cell pigment to return to its previous level was then observed, and the influence of a variety of dietetic factors noted. On an ordinary diet of mix-ed table scraps the time taken for a complete return to normal was four to seven weeks. On a liberal diet of meat and beef heart 
however, the time was only three to four weeks, while with cooked liver it was even less (two to four weeks). Watery liver extract had a distinct, but very slight, influence on blood regeneration, but of course the dosage may heve been insufficient. Commercial meat extract was found to be inert. It was found that the active foodstuffs could be given either alone, or in combination with other foods, and that they' would stand the severe test of pro-moting definite blood regeneration when administered after long 11 ited-diet periods unfavorable to blood regeneration." "

"Studies on blood regeneration were also reported by Jencks in I922. Regeneration was found to be more rapld 'with protein than with e1ther carbohydrate or fat, when fed as a sole nutrient, and a diet of vitamine-rich food gave somewhat more speedy regen-eration than any other diet containg only one food factor." The foregoing quotation is taken directly from an essay on the treatment of Perniclous Anemia by Dr. J.G.McCrie, as quoted by Goodall and Davidson, and summarizes briefly but successfully the earliest reports on successful dietetic treatment. The writer has gone over the articles summarized personally, and believes this as excellent a resume as could be used within the scope of this paper.

In I925, Whipple and Robscheit-Robbins reported further work along this Iine, in which they had produced a constantly main-tained severe secondary anemia, in place of the single post-hemo-rrhagic anemia of their previous experiments. They maintained the hemoglobin level of their dogs at between 40 and 50 percent by repeated bleedings of estimated amounts, and used the blood obtained to estimate the total hemoglobin present, and from these figures 
were able to follow the rate of blood regeneration. Also, the maintenance of the constant hemoglobin level kept a more cons-tant stimulus to blood regeneration, and thus the sudden initial stimulus of a single hemorrhage did not have to be reckoned with as a possible confusing factor in the interpretation of the re-sults of the dietary therapy. By this method they found that while in the previous short,immediately post-hemorrhagic anemias beef muscle, heant, and liver were equally efficaclous, in treating the more severe type of anemia produced by repeated hemorrhages the maximal effect was obtained by the feeding of beef Iiver, beef heart being less valuable, and beef muscle still less. The final conclusion reached by these workers was that "Liver feeding in these severe anemias remains the most potent facto for the sus-tained production of hemoglobin and red cells. This favorable and marked reaction is invariable in our dog experiments, no matter how long-continued the anemia level, no matter how unfavorable the preceding diet periods may be, and regerdiess of the substances given with the liver feeding."

One other plece of work which was reckoned as bearing on the possible application of such a detary to the treatment of Pemiclous Anemia in humans was a group of experiments perfomed by Baker and Carrel, in I925. These Investigators found that Iipolds, both those occurring naturally in serun, and those extracted from various tissues, had an inhibitory action on the growth of fibroblasts in vitro. Koessler and Maurer, two other Amerlcan workers, In I926, had also emphasized the importance of a possible connec-tion between vitamine $A$ and blood regeneration, after conducting 
a series of feeding experiments on rats rendered anemic by re-peated hemorrhage, and recommended a balanced diet containing necessary vitamines in the treatment of primary and secondary anemias.

Repeated animal experiments by the foregoing group of workers have furnished significant hints as to the possible succ-essful application of a Liver and Vitamine Rich, Low Fat diet in the treatment of Pernicious Anemia. Minot and Murphy, in Boston, have become interested in this information and have determined to test out its value in cases under their observation, and the stage is set for an announcement which will be received by the world as one of the greatest advances in treatment ever made. In August, I926, Minot and Murphy made their first report on the treatment of Pernicious Anemia by the new dietary. A series of 45 cases were reported as having received a diet rich in liver and red meat, relatively poor in fat, and containing an abundabee of fresh fruit and vegetables, for periods varying from six weeks to two and a half years. This diet consisted of,daily, I20-240 gm. of cooked calf or beef Ilver; I20 gm. of red meat; not less than $300 \mathrm{gm}$. of vegetables; $250-500 \mathrm{gm}$. of fruit; $40 \mathrm{gm}$. of Fat; an egg if desired; $240 \mathrm{gm}$. of milk;dry crusty bread;potatoes; cereals---to give a total calorific value of 2000-3000 (340 gm. carbohydrate; I35 gm. of Protein; not more than $70 \mathrm{gm}$. Fat). Sugar was used sparingly;grossly sweet foods were prohibited.

$\mathbf{A}$ few, at first, had been unable to take the full diet, and in them liver alone was "pushed". Within a week to ten days 
all were able to take the diet and exhibited a "ravenous" appet-ite. The bowels became more regular. Four of the forty-five died, but all of these were so 111 from the beginning that they could take no liver. The remainder all improved,irrespective of the length of time the disease had lasted before the treatment was begun, and all were pronounced "well" at the time of publication. By the end of the first week of treatment the reticulated red. cells of the blood had risen markedly, returning to a normal level by the end of the second week, and at this time the red cell count and hemoglobin percentage were beginning to show noticeable impr-ovement. The rate of improvement was found to be greatest in those who had the lowest initial counts. After four to six months of treatment no patient had less than $3,500,000$ red cells, $81 \%$ had 4,000,000 or more; and 30\% had over 5,000,000. The lcterus index had usually fallen to below normal by the time the red count had reached $2,500,000$. Those patients who were most careful in taking the full amount of liver improved more quickly than those who were careless in this regard. Three of the patients relapsed,but it was show that they had not been taking their diet as they should have, and marked improvement foldowed the institution of the proper dietary schedule. In their conclusions, Minot and Murphy called attention to the well-known phenomenon of natural remissions in the disease, but pointed to the regularity, measured by reticulocyte increase, with which the remission in their cases had commenced within a week after the beginning of the treatment. They also call -ed attention to the fact that each natural remission tends to be 
less complete than the one before, and in contrast to this point out the fact that in their series of cases they had many patients who had had previous remissions, during none of which had their red cell count reached the high level which it attained under the new dietary regime. As the experiment had been carried further, these workers found that the low fat content in the diet,prompted by the earlier researches of Baker and Carrel, was of minor import -ance to the high protein diet constitulent. In a paper issued at a slightly later date these workers made public sample menus that had been successfully used by them.

Save for the work of Banting and Best on Diabetes Mell-itus, no medical announcement in the last three decades has arou-sed more of a furore. Physlcians all over the world eagerly siezed this new method of treatment, hopeful that it would not prove another false hope, while thousands of sufferers from the disease which it combatted took hope. For the few months follow-ing this announcement every medical journal bore reference to its posibilities, and soon reports came drifting in from other workers who had met with success with the use of the new diet. The long sought-for specific treatment for use against Pernicious Anemia seemed to have been fount.

At this juncture medical men began to speculate as to what might be the factor contained in this Liver diet which was responsible for this miraculous change in cases treated. Was it the fact that some substance within the liver fea supplied. material for the stroma of the red cells, allowing a normal number 
of these to be formed? Was it the Vitamin content of the material ingested? Was it V1tamin A, as suggested by Koes aler? Or was it some as yet unthought-of factor?

A possible explanation of the action of Liver was advanced in Apri1, I927, when these same workers demonstrated that rats, when fea with iron in the form of ferrous salts, were unable to assimilate it properly in the absence of Vitamine $E$, and soon developed deficiency symptoms, while the substitition of ferric salts or the adition of Vitamin to the diet resulted in the nornal utilization of iron by the body. Ergo, reasoned these workers, perhaps the beneficial action of Ifver in Pemicious Anemia is due to the fact that the Iiver fat contains consideram - ble Vitamin $E$, and the Inver Itself contains an appreciable amount of iron. They pointed to the fact that the benericial effects of the diets used by Koessler, and attributed by him to the presence of Vitamin A could just as probably have been due to the action of $E$.

In the same month Murphy published a further account of his resuls with Liver therapy in ten cases. In this paper he call -ed attention to the reticulocyte crisis, the fall in the icterus index, the rise in the red cell count and hemoglobin percentage, the fall in color index, the increase in the numbers of circulating leulocytes and platelets, disappearance of abnormal forms of red cells, rlse of corpuscular and whole blood volume, plasma volume remaining constant, the constant level of non-protein nitrogen and. 
protein nitrogen in the plasma, and the increase of circulating protein to an extent accounted for by the increased.quantity of hemoglobin.

The next step toward solving the question of the role played by the Liver in treatment of anemia was made by cohn, who, later in this same year,prepared a water-soluble fraction from whole liver which had a beneficial effect comparable to that of Liver itself. This fraction was insoluble in ethet, (proving that its action was not due to the content of Vitamin $E$, which is not soluble in water, and is soluble in ether), was precipitated by alcohol, and contained no lecithin or any of the ordinary lipolds. Murphy and Minot, using this extract on their cases, reported that patients responded quite favorably to its use. This disproved the postulate that liver acted by furnishing some absent material for the red cell stroma, since it would not be contained in a mere aqueous extract.

st this time favorabie results were reported from the feeding of large quantities of kidney to Pernieious Anemia patients, but thes was not deemed as efficient as the Iiver diet. However, it did point to one significant fact, namely, that the therapeutic agent was not contained in liver alone.

Also during the year I927 another quite pertinent question was raised by Peabody. This worker had shown that during the stage of relapse in Pernicious Anemia the bone-marrow was crowded with primitive myeloid cells, megaloblasts, the first differentiated form of the erythrocytic Iine. In the stage of remission, however, he found that the predominating erythroblastic cell was the 
normoblast, and that the appearance of the marrow was nearly, if not entirely normal. These findings prompted Peabody to teach the very sensible conclusion that the vital factor involved was quite probably in the nature of a stimulus to normal erythropoiesis, which, in the case of the patient with Pernicious Anemia, was lacking.

In September I927 Minot and Murphy published a report on further cases, including, in all, IO5 cases which they had treated with the Liver diet, some of whom had been under observation for three years. Of these, three had died, but in no case was death due the Pernicious Anemia. Of 90 patients who had started treatment when the ref count was below $2,700,000$, I0 who took the diet 2. badly averaged 3,500,000 after 4 to 6 months; the remainder all averaged $4,790,000$; and 44 had a red count of over $5,000,000$. These workers emphasized the need for a maintenance diet of Liver after the blood count had reached its normal level if the patient were to remain well. Fatients who had had repeated previous transfusions had not responded so well as those who had not, and the presence of complications such as infection, or cirrhosis of the Liver, also mitigated agalnst the maximal desired response.

The improvement in the state of the patients was descri-bed by Minot and Murphy. Beside the points remarked on in their previous papers, they called attention to the following: the disappearance of fever; a pink flush to the cheeks; early loss of weight from the disappearance of oedema;increased appetete and sense of wellbeing; disappearance of glossltis and gastric sympt-oms In spite of the continued absence of free hydrochloric acid 
In the gastric fuice); the diminution in size of the liver and spleen, if previously enlarged; the clearing up of scaliness,plgmentation, purpura, and other skin lesions; and the disappearance of catdiac pain in those patients who had exhibited this rather uncommon symptom. There was no evidence of renal injury, attribut able to the liver diet, nor was there any hypertensive trend. In a few cases Bursitis had developed, while in others a pre-existing arthritic condition had been improved. In regard to neural signs, no case showed further progression of symptoms, while some, especi-ally those who had been afflicted with earlier signs, such as parasthesias, had actually undergone improvement. Patients who had received no Hydrochloric acid had improved equaliy as well as those who had. Excess of Fat had not been found, as was first thought, to inhibit the rapid improvement in the condition of the blood. Finally, these workers claimed that the success of this mode of treatment was such that, if a case showed little improvement after $\mathrm{six}$ weeks of treatment, the diagnosis of Pernicious Anemia was probably wrong.

During the following year many reports are to be found in the literature of successful cases under Liver therapy. Many Blological and Pharmaceutical houses began the manufacture of the liver extract isolated by Cohn, and in I928 he and his co-workers succeeded in still further purifying the extract by a precipitat-ion method with Phosphotungstic acid. From this work, a fraction has been produced which will produce a typical response if given in a dosage of $0.6 \mathrm{gm}$. daily, and at the peesent time nearly all the leading Pharmaceutical houses have a reliable brand on the 
mariet. This extract is of especial value in the treatment of Pemiclous Aneria in patients whose stomachs are upset and who cannot tierate whole liver. It should be used in all cases in which renal damage exists with concomitat increase in blood urea. It is, therefore, valuable in that type of Perntcious Anemia associated with pregancy, as some of these cases show albumin and casts in the urine; and it to be used in all other cases of Pern- iclous Anemia in patients for whom a low protein diet is indica-ted, since it contains only a trace of protein, as well as supphur and iron.

During this same year (I928) Ordway and Gorham tabulated the results of liver therapy published in every country. These authors Included no case which started treatment during the period of a remission, and hence their list excludes many hundreds which might rightfully be included. They found that 578 cases had at this time started treatment with Liver or Iiver extract with an average red count of $I, 500,000$ and had finished with an average of 4,000,000. Attention was called to the fact that the average should have been higher, but that many cases felt so well by the time their red cell count had reached 3,500,000 or 4,000,000 that they would leave the hospital for their homes, where blood tabulations were diffe-ult to obtain. Seyderhelm, during the same year, collected I50 publications dealing with 2000 cases. All of these had benefitted by Liver treatment, only 20 falling to give the desired response. What a world of contrast exists between these twoo summaries of - treatment given above and the summary of Panton and Valentine of cases treated prior to the advent of Liver therapy, previously 
cted.

In June, of the following year, Castle published an article In the British Medical Journal, dealing with certain experimen -ts by which he had determined that the stomach of a normal person secreted a substance which would develop a blood-matur - ing principle from meat ingested. Quick to recognize the pot-entialities of this discovery, Sturgis and Isaacs, of the Undv -ersity of Michigan, decided to test the activity of gastric thasue itself In the treatment of Fernicious Anemia. Theae ex- periments were later carried out with Dr. Sharo, of the Parixe Davis Research Laboratomes. Fresh whole hos stomach was used by these workers, and it was so dessicated that 30 grams of the dried product was equivalent to 218 grams of fresh tisue. By extracting the fat from the pedidue with petroleum benzine, the manked concentration was made possible. This product had very I1ttle odor or taste, and was substituted for liver extract in the treatment of 3 cases of Pemplous Anemia. From the quite favorable results obtained from these 3 patients it was con- cluded that this dessicated stomach extract, or Ventriculinm is more active than Iiver, as smalier amounts of $1 \mathrm{t}$ had been needed in order to produce a remisaion. Sturgis and Isaacs stated at this time m- "The question of the origin of the active principle is being tested. There are several possibilities. One is the pres- ence of an enzyme, or similar substance, which may act on protein present in the stomach tissue during the period that elapses after the organ is removed and before it is dried. (This agrees 
to a marked extent with the conclusion reached by Castle.) Another possibility is that there may be a supply of the active hematopoletic principle itself present in the stomach wall, as it apparentIy is in the liver and kidney. We are not cortain as to whether this is in muscularis or mucosa, or both. The observations so far are in accord with the idea that those suffering from Pernicious Anemia have evidently lost, or never had, the ability to secrete a substance in their stomachs which has the power to produce a bldod-maturing material from food." As a result of these announcements, various clinfoians at once tried the efficiency of Ventriculin the treatment of cases then under observation, and since that time many controversies have been held as to the respective merits of liver extract and the newer dessicated stomach preparation. Anderson, in I93I, clies several cases which came under his care, which did not respond nearly so well to liver therapy as they did to Ventriculin. Several charts have recently been circulated by the producers of the latter, which give a graphic 1llustration of its superior-ity over liver extract. However, this still remains a moot point as far as therapeutic effect is concerned.

While Minot, in 1929 , demonstrated that a rapid remiss-Ion in Pernjcious Anemia could be brought about by the intravenous injection of an extract of liver, and Castie and Taylor reported favorable results in a case which had not responded to orally administered liver, it has not been until the last year or so that such a preparation has been placed on the open market. At least one leading pharmaceutical and biological house in the 
United States now has both an Intra-muscular and an Intravenous extract for generel use. These solutions are refined by a process which eliminates toxic nitrogenous substances that might produce severe constitutional reactions if injected. The dosage of such an extract,especially of the intra-venous type, is small compared with the amount needed for oral therapy under similar conditions. The parenteral administration of such extract would seem to be especially adapted to cases that show an increasing exhaustion of the bone marrow and do not respond readily to the average dosage of the oral preparation: also to the requirements of patients whose digestive function is so impaired that the antianemic substance when siven oraly is only imperfectly assimilated. In adition, it is claimed by those who have used the intra-venous extract, that, after an individual's red cell count has been restored to normal, an average of one ampoule by vein per month is sufficient to keep it up. Compare such magical reaults with the hopeless therapy of the period ending five years ago!

During the recent two or three years research and speculation as to the nature of the vital factor contained in these extracts has been marked. Davidson and Gulland believe It to be a poly-peptid or a nitrogenous base. Others have the conception of a hydroxy-glutamic acid. Whatever its actual composition, the fact that it is present in the nomal stomach, in meats digested by the normal stomach, in the liver, and, to a lesser extent, in the kidney, suggests the nature of a hormone, 
an amino-acid complex, or an amino-acid, as yet unknown to us, the lack of which, whether due to a congendtal tissue debility or to other factors, results in a perverted stimulus to the hemopoletic tissues, and causes the clinical condition which we know as Perniclous Anemia, a deficiency disease.

Both experiment and clinical experience have proven that if the patient expects to sustain permanent remission from symptome he must ever afterward continue the use of the vital principle in some form or other. Since the expense of the divers preparations to the patient, as well as their avallability and convenience, must be considered, the following data obtained from Parke-Davis and Company, are worthy of note. The maintenance dose of Liver Extract is 3 vials daily; that of Ventriculin I vial daily. Going at a maintenance rate, the patient would pay $671 \%$ per day for the Liver Extract, and 26: or less daily for Ventriculin. Respectively, this would come to 420 . Io and $\$ 7.80$ per month, the Ventriculin being by far the more within reach of the average patient. However, the new ampovies of Intravenous Liver Extract, of which one per month is estimated as sufficient to maintain the red cell level at its nomal, cost only 2.00 . To what a degree this mode of treatment w11 alsplace the other two previously considered remains to be seen. However, it is, from these qudtations, quite evident that the necesam therapy to regain and maintain heaith is within the reach financially of practically every individual. 
PRESENTATION OF CASES

Case I.

This case, while not presented completely as far as the laboratory findings are concerned, sone of especial interest to the writer for two reasons -... first, because it illugtrates clearly the hopeless efforts of therapy prior to institution of Iiver diet, and second, because it was observed from beginnings to end in the writer's own family.

The patient, a wonan 53 years of age, first complained of weakness on exertion and ahortness of breath after unusual exerolse such as walking out-of-doors. Soon arter this she not- Iced numbess and tingling of the lower extremitses, and had some difficulty in walking because of spasticity and uncertainty as to the postion of her feet. At this Juncture the patient had the misfortune to fall, severely spainingan ande. After all the swelling and pein had lert this member and almost two weeks had passed she tried to begin walking agein, and found that she was unable to do so without maintalning hen balance by cinglng to nearby articles of furniture. At this time the attending phy- solar took a blood count and suspected Pemioious Anemia. The patient was brought to omaha, and placed under the care of two of the eity's best internista. Thile I do not mow the laboratory data obtained, I know that the tentative diagnosis of pernicious Anemia was confimed. During her three weer atay in the Onaha 
hospltal bhe recleved the vavel medication of the day, consist. -ing of dilute Hydrochloric Acla, Fowler's solution, ard some Iron compound, as well as two transfusions of 500 cc. each. She was sent home IIttle improved, and from then whtl ber death, three weeks later, rapidly declined. Evidence of progressive cord. changes was present, with almost complete loss of sphincter con-trol, and lassitude and cachexia increased until the exitus. The rapid and inexorable progress of the disease, unchecked by the efforts of proficient physicians, shows how inadequate was the teatment of the day, and offers a pitiful and ironic sort of contrast to the results obtained by the Murphy-Minot diet, which was made public just three month later. Case 2.

This case, while coming under the attention of a competent physiclan after the Murphy-Minot diet was generally accepted, is 11Iustrative of the somewhat hopeless plight of the sufferer from unrecognized Pernicious Anemia who became the victim of an acute infection calling for the mobilization of body reserves which were already sady depleted.

The patient, a woman 33 years of age, who had been in a somewhat "run-down" state for several months, was brought to a local Omaha, Hospital under the care of a capable internist, with the clinical diagnosis of lobar preumonia. On entry, the bloodploture was as follows; R.B.C.2,240,000, Hb.30., Color Index.6. W.B.0.4,46o., granulooytes 58\%, Iymphocytes 42\%. There was a marked anisocytosis and poikilocytosis, with much polychromato- 
- philia. The temperature fluctuation was between 96 and I04 degr -ees, and the pulse rate varied from 80 to I00, with moderately accelerated respiratory rate. In spite of all possible support -ive and stimulatory treatment, the patient showed only slight registance to the pulmonary involvement, and succumbed on the fourth day after entry. Had the patient's marrow reserve been prepared for the sudden demand made upon it the outcome of the pneumonia might have been the opposite, but she had been carrying on for month ignorant of the disease which robbed her of what chance she might have had.

Case 3.

This case entered a local hospital under the care of the same physician attending the previous case cited,complaing of marked weakness, numbness and tingling of the lower extremities, and general debility, of several month's duration. The blood-pleture on entry was as follows, and a diagnosis of Pernicious Anemia was made: R.B.C. 2,400,000. Ho.45., Color Index.9

W.B.C. 5,000. Granulocytes 60\%, Lymphocytes 40\%. There was merked anisocytosis and polkilocytosis, with polychromatophilia and nucleated red cells present. The patient was found to have no free Hydrochloric Acid in her stomach during the test meal.

She was placed on the Murphy-Minot diet, and recieved dilute HCI gtt.xW tidpc; Bone marrow, tablets one, tidac, and Blaud's pills, one tidac. A sumary of her various blood-plctures from that given above,5-I9-27, until her dismissal, 6-I5-27, will reflect the improvement in the clinical condition and the return to an 
evident state of heaIth.

5-23. R.B.C.2,800.000 Hb.45. Color Index.9

W.B.C.5,000. Granul ocytes 56\%. Lymphocytes $44 \%$.

5-3I.R.B.C.3,000,000 Ho.52. Color Index .8

W.B.0.6,000. Granulocytes 62\%. Iymphocytes 38\%.

6-4. R.E.C.3,200,000 Hb.58. Color Index 9

W.B.C.6,800\% Granulocytes 70\%, Lymphocytes $30 \%$.

6-IO. R.B.C.3,400,000 Hb.62. Color Index.9

W.B.C.7,400. Granul ocytes54\%. Lymphocytes $46 \%$.

6-I4. R.B.C.3,900,000 Hb.64. Color Index .8

w.B.C.8,200. Granuiocytes 64\%. Lymphocytes $36 \%$.

Surely the marked improvement under the new dietamy regime will speak for itself, in the light of its contrest with the cases previously cited.

Case 4.

The patient, a man aged 53, was brought to Dr. with

a probable dagnosis of Carcinona of the Stomach. He had no appetite; had been confined to his bed for one month; had lost 30 pounds in weight during the past 6 months; and was extremely weak. A clinical diagnosis was made of Pernicious Anemia. His red cell count at the time of the first examination was $I, 800,000$ and his hemoglobin stood at $40 \%$. A tranefusion was given, and the patient was placed on Ventriculin therapy, improvement soon being apparent. Within ten months his blood count was normal, he was able to do Ilght work on the farm, had a good appetite, and had regained his welght, and was taing only three doses of Ventricul - in a week.

This case well 111 ustrates how, with proper diagnosis and rational guidance of treatment, the patient may be given carte blanche and allowed to gauge the amount of medication to be taken by his general condition and wellbeing, when circumstances do not 
permit him to be constantiy under the observation of his physician.

Case 5.

This case gives an interesting side-Iight on the comparative Values of Liver Extract and Ventriculin in the opinion of the physician who obligingly gubmitted this case history.

The patient, the manager of a planing mill, aged 65, came into my offec complaining of $10 \mathrm{~s}$ of appetite, nausea, manked wearnesis, and shortness of preath, of a duration of three nonthe. More recently he had been bothered by numbness of the hands and feet.

On Feb.20, the red blood count wes I, I40,000, hemoglobin 30 , color Index I. 5 ; the white count was 2500. A amear showed marixed poikllocytomis and andsocytosis. Blood platelets were rery much diminished. Te was unable to retain food or mediction of any Kind, as he vombted everything we gave him except water and orange Juice. On the next day we gave him a blood transfusion of 500 cc. by the citrate method. On the following day he was able to retain his food and also Ventriculin. He took Ventriculin, 30 Grams a day, from February $2 I$ ti11 Maroh 5 . His blood count then was $2,750,000$, with a hemoglobin of 48 , and a color index of 9 . At this time he felt much better and had lost all sastric aism tress, but was still very weak.

I then stopped Ventriculin and gave him Iiver Extract, one vial three times a day. This was taken until the 2Ist of March, when his red blood count showed 2,400,000, with hemoglobin 
at 52, and color Index of I. At this time I stopped the Liver Ixtract and put him again on Ventriculin, one bottie three times a day. On April 6 his red count had risen to 4,400,000, with a hernoglobin of 70 , and a color lndex of .7. The dosage of ventricUlin was decreased to two vials a day, and on April $2 I$, his red cell count had risen to $5,400,000$, with a hemoglobin of 90 and a color index of .8. He had gained about 20 pounds in weighty his cheeks, once pale, were rosy, appetite good, and able to eat anything he wished. From this time (April 2I) until August 9, the dosage of Ventriculin was gradually diminished until the patient was taking only one vial a week. His red cell count stood at 5,400,000, with a hemoglobin of IOO and a color index of .9.

I have six other patients on Ventriculin, and I must say that I consider it by far the best treatment we have for Pern- icious Anemia. While giving liver has given marked results, I find that my patient's red counts increase much faster under Ventriculin and that the dose cah be reduced much sooner."

Whether or not all other physicians would agree with this one in his whole-hearted endorsement of Ventriculin, it is safe to say that the improvement of the patient in this case, when viewed through the gloomy light of therapy of former years, was little short of miraculous. 
Case 6.

The patient, a woman aged 63, entered a local hospltal complaining of extreme weakness, loss of weight, jaundice, anorexia and nausea, numbness and tingling of the extremities, and diffeulty in walking, of a duration of three months. Two and a half years previously she had been under treatment for pernicious anemia, had been relieved of the minor complaints of that date, and had ceased the prescribed diet. On entry, there was mental confusion, at times almost amounting to a deIirium.

Physical examination revealed nearly every cardinal diagnostic feature of pernicious anemia. The sclerae were icteric, the skin exhlbited a waxy, lemon-yellow tint, and all the mucous membranes were quite pale. The tongue was bald and glistening, and the patient recalled recent soreness of this member. There was no palpable evidence of enlargement of either Iiver or spleen. A soft systolic blow was heard clearly over the mitral and systolic areas. The abdominal reflexes were missing, and patellar reflexes were also gone. There was a positive Babinski sign on the right.

The urinalysis was negative save for a marked trace of albumen. The blood-picture was as follows:

R.B.C.I,050,000 Hb. 20 Color Index I. There was extreme anisocytosis and polkilocytosis, and many megalocytes were present, as well as a fair number of normoblasts. W.B.C.3,800. Granulocytes 46\%, Myelocytes $2 \%$, Lymphocytes $44 \%$. 
She was put on a diet including Liver, I00 Grams, twice daily;

She also received beef kidney, heart, and sweetbreads at various meals. Twice daily, at breakfast and lunch, she recelved one of the following fruits-.-- apricots, peaches, prunes, or apples. In adalion to this diet she was given 4 vials of LiIIy'a Liver Extract daily, and $2 \mathrm{ce}$. dilute Hydrochlonic acid three times dally.

Due to her extreme condition, it was decided to push the Liver Extract harder, and on the next day she received 6 vials, 2 In the morning and 2 in the evening, with $I$ at noon and at dinner. However, marked nausea supervened on the evening of this same day, and the patient became semi-comatose, with complete los: of sphincter control. On the following day, the third day after admission, the diet with Liver Extract as specified, was continued, but, since the patient was unable to retain but a fraction of this det because of emesis, she was given I vial of Liver Extract by milk retention enema every four hours, and also received I ampoule of Intramuscular. Liver Extract (Lederle) Intragluteally. During this day her general condtion was such that both adrenalin and cafiene-sodio-benzoate had to be ueed as stimulants.

on the following day there was still considerable of the nausea, but the general condition was not quite so precarious. Treatment was much the sane as on the previous day, and patient was able to retain a measoneble amount of fluid in the form of frult julce and broths. During the next 13 days there was but Iittie clinical improvement, and so the patient was given 250 co. of whole blood by transfusion. On the following day (the fifth 
after her admision) her blood ploture was as follows:

R.B.C.2,300,000 Hb.30 Color Index .? The appearance

of the red cells was much the same as before, and there

had been only a slight retioulocyte response.

The same diet sohedule, with Liver Extract, vials 4

dally was kept in force, and, in addition, the patient recelved

2 intra-giuteal injections dally of 200 . Intra-muscular Liver

Txtract. Muriatogen, tablets 2, was given with each meal, and

Iiver extract was continued by retention enema every four hours.

on the seventh day after admission the general condition

had improved moderately, the patient being able to talk ration-ally with her family and to taie her meals and retain them.

On this date her blood-picture was as follows:

R.B.C.2,400,000 Hb.3I Color Index.6. At this time the reticulocyte response was evident, the percentage of the reticular cells being $I 6$.

m.3.C. 4,360. Granul ocytes 46\%, Lymphocytes $52 \%$.

During the next four days there was steady improvement in the patient's zeneral condition, and the diet and medication already outlined were continued in force. At the end of two weeks in the hospital, although the red cell count had not increased materially, the patient's condition seemed so good to her family that they took her home. However, at this time the reticulocyte response had reached a good peak, and the attending physician, appreciating the economic factor, consented to her removal and continued treatment in the home. At the end of two months, during which time the 
patient was on a modified Murphy-Minot diet and was taking 3 vials of Liver Extract daily, the red cell count had increased to over $5,000,000$, the hemoglobin had risen to slightly less degree, and the patient was relieved of all her complaints save for occasional paresthesias in the extremeties. At present, she is taking only one vial daily, and is able to be up and about, eat freely, and enjoy her former routine of existence. This case, more than any other which I have ever seen, IIIustrates how radicie Liver therapy, given by mouth, by rectum, and intra-muscularly, can change an almost moribund person to a person of normal health and vigor within an amaingly short time,

Six years previous to this writing, this patient would have been dead within a week after entry into the hospital. 


\section{SUMIMARY}

The Treatment of Pernicious Anemia has been traced from the time when the disease was first recognized as an entity, with a hopeless prognosis, to its present status of a deficiency disease, readily amenable to treatment with the recently discovered vital anti-anemio principle contained in the Liver and in the Stomach wall.

Cases have been presented to illustrate the end results obtained by the various means of therapy in the diff-erent periods of the evolution of the present treatments at our disposal.

Pernicious Anemia has jolned the ranis of the other diseases which modern medical science has brought back from the limbo of the hopeless to the light of successful treatment. 


\section{BIBLIOGRAPHY}

I. Addison, Thomas. "Constitutional and local effects of disease of the Supra-renal capsules." S.Highly, London, I855.

2. Anderson, A.I. "Six Cases of Pernicious Anemia treated with Ventriculin." Therapeutic Notes, Parke-Davis, Dec.,I93I.

3. Aschoff, Ludwig. "Lectures on Pathology". "The Reticulo-Endothelial System." New York, I924.

4. Ashwell, Dr. "Observations on Chlorosis and its complications." Guy's Hospital Reports, I836. Series I, Volume I, Page 553.

5. Baker,L.E., and CarreI,A. "Lipoids as the Growth-inhibiting Factor in Serum." Jour. Exper. Med. I925, xI11, I43-54.

6. Barclay, A.W. "Death from Anemia." Med. Times, I85I, xxi1i, 480.

7.Biermer, A. "Form von progressiver pernicioser anamie mit verfettungsvoangen in den circulationswegen." Correspondenz-Blatt fur Schweizer Aerzte, I872, i1, I5

8. Boggs, M. "Favorable results obtained by treatment of Pernic- Lous Anemia with Salvarsan." Jno.Hopk.Hosp. Bull. oct. I9I3.

9. Bramwell,Byrom. "Clinical lectures on a case of Progressive Pernicious Anemia cured by Arsenic." Ned. Times and Gazette, I877, 111, 323-324.

IO.BramwelI, Dr. "The Use of Salvarsan in the treatment of Pernicious Anemia." Brit. Mee. Jour., May 24,I9I3.

II.Castle,W.B. "Achlorhydrie and Pernicious Anemia." Brit. Med. Jour., I, II20. June I929

I2. Castle, T. B. "The Value of Pre-digested Muscle veats in the treatment of Pemiclous Anemia." Am.Jour.Med.Sc., Dec., I929 
I3.Cohn, I.J., Minot,G.R., et al. "The Nature of the material in Liver effective in Pernicious Anemia." J.Biol. Chem.I927, Lxxiv I4. Cohnheim, J. "Irizrankung des Knockenmarke, bei pernicloser anamie." Virchow's Archiv, I876,Lxvi1i, 29I-293.

I5. Combe,J.S. "History of a case of Anemia."

Trans. Ned,-Ohir. Soc. Edinburgh, I824, I, I94-204.

I6. Coupland, Sidney. "Treatment of Pernicious Anemia."

Allbutt's System of Medicine, Vol.V. MoMilian and Co.,I898.

I7.Daviason,L.S.P., and Gulland,G.L. "Pernicious Anemia."

O.V.Mosby and Co., St.Louis, I930.

I8. Thrlich, P., and Lazarus, A. "Die Anamie."

Nothnagel's Pathologie, Banö.Vili, T.I. A.Holder, Wien, I898.

I9.Fitch, H.F. "Dietotherapy." 2nd Edition.,iii,25I.

D.Appleton and Co., New York, I922.

M. Fraser, TI. "Bone Marrow in the treatment of Pernicious Anemia" Brit. Ned. Jour., 1, I894.

2I.Hare,H,A. Textbook of Practical Therapeutics. Lea and Febiger 22. Henry, F.P., and OsIer,, $\mathrm{m}$. "Atrophy of the Stomach with the clinical features of Progressive Pernicious Anemia." Am. Jour. Med. Sc., I886, xc1, 498-5II.

23. Hunter, Sir Hm. "Observations on the treatnent of Pernicious Anemia, based on a study of its causation, with notes of a case" Brit. Med. Jour., I890, JuIy I2.

24. Hunter, Wm. "Severost Anemias." VoI.I. Momillan and Co. London 25.Jeneks, $z$. "Studies in the Regeneration of BIood." Am. Jour. Physiol, I922, I1x, 240-253. 
26.Koesgler, K.K., and Maurer, s., et al. "The Relation of Anemia, Pximary and Secondary, to Vitamin A Deficiency." J.A.M.A., I 926, LXXXV11, 476-82.

27.Iichtheim,H. "Zur Kentnis der pernicioser Anamie."

Verhand. a.Kong.f.in. Ned. 6:84-99. I887

28. Mande1, Dominique. "Instruction sur les vertus de la bovle d'acier de Nency. Les cures operees par ce specirio at les moyens de s'en servir." Publiee par Iui-meme, 1804. 29. Minot,G.R., and Murphy, w.P. "Treatment of Pernicious Anemia by a Special Diet." J.A.H.A., I926, Ixxxyi1,470-76. 30.解not,G.R., and Murphy, H.P. "A Diet rich in Liver in the treatment of Pernicious Anemia." Ibia., I927, Lxxxix,759-68. 3I. Minot,G.P., and Murphy, W.P. "Treatment of Pernicious (Adison-ian) Anemia with a Diet rich in Liver." B.W.J.I927,11,674. 32. prinot,G.R., and Murphy,W.P., et al. "The Feeding of Whole Iiver or an Effective Fraction In Perricious Anemia. the Response of the Retioulocytes." Tr.A.Am. Phys.I927, xIi1,83-86. 33. Wur, R. "On the Changes in the Bone Marrow in Pemictous Anomia." Jour. Path, and Bact. I894, 11, 354-66. 34. Ordway, T., and Gorham, I. W. "The Treatment of Pernicious Anemia whth Liver and Liver Extract." J.A. .A.I928,xet, 925. 35.Panton, $\mathrm{C} . \mathrm{N}$., and Valentine, F.C.0. "An Inquiry into Results of Liver Treatment of Pernicious Anemis." Lancet, I923, i, 872-74. 36. Peabody, F.w. "The Pathology of the Bone Rarrow in Pernicious Anemia." Am.Jour.Path., I927, iii, I79-202.

37.Pepper, Wm. "Progressive Pernicious Anemia, or Anaematosis." Am.Jour. Hed. Sc. I875, Lxx, 3I3-42 
38. Piney, A. "Recent Advances in Hematology." Edition 2. Blakigton's Son and Co.,Philadelphia, I928.

39. Pye-Smith,P.H. "Renort of a case of Idiopathic Aneria of Addison, since called Essential, Pemiciou, or Progresaive Anemia." Guy's Hosp. Reports, Sertes Ii1, Vol.xxv1, I882.

40. Quincke, H. "Veber pernicioser Anenia."

Sami.KIin.Vortr., No. I00, Leipz., I876.

4I.Robscheit-Robbins, F.s, and Whipple, C.H. "Blood Regeneration in severe Anemia." II. Favorable Influence of Liver, Heart, and Skeletal muscle in the Diet. Arm.Joux. Physiol. I925, Lxxi1, 408. 42. Rous, Peyton. "Destruction of the Red Blood Corpuscles in Health and Disease." Physiol. Reviews, I923,ili,75. 43. Seyderhelm, "Die Behrndiung der pernicioser Anamie." Verhandl. d. deutsch. Gesellsch. f. Im.Med., I928, xI, 音I5-25. 44. Short, sir Rendle A., "An Index of Prognosis and Ind-results of Treatment." Sir. Jno. Wright and Sons, Bristol, I922. 45. Sturgis, C.O., and Isaacs, R. "Dessicated Stomach in the treat-ment of Pernicious Anemia." J.A.M.A., xciii, $747-49$.

46. Taylor, Frederick. "A Contribution to the History of Idiopathic or Permicious Anemia, with cases." Guy's Hosp.Reports, Series3, Vol.xxIII, Pg.I83.

47. Whipple,G.H.,Hooper, O.W., et a.I. "Blood Regeneration following Simple Anemia." I. Hixed. Diet Reaction. Amer. Jour. Physiol., I920, L111, I5I-66. Whipple,G.H., Hooper, O. W. ,et al. Ibid. II. Fasting compared with Sugar feeding. I67-205. 
48. Whipple,G.H., Robscheit,F.S., et al. "Blood Regeneration following 3imple Anemia".IV. Influence of Meat, Liver, and various extractives, alone, or combined with Standard Diets." Ibid. $236-62$.

49. Whipple,G.H., and Robscheit-Robbing,F.S. "Blood Regeneration in Severe Anemia". I. Standard Basal Ration and Experimental methods." Ibid. I925, Ixxi1,395-407.

50. Hale White, . "On the Pathology and Prognosis of Pernicious Anemia." Guy's Hosp.Renorts,Vol.xxv11, Pg.I49. 
RECEIVED UNIVERSITY OF NEERASIA

AP 1 - 1932

OFFICE OF THE DEAN COLLEGE OF MEDICINE 